\title{
Investigating Coastal Processes and Nitrate Levels in the Elkhorn Slough Using Real-Time Data
}

\author{
BY LISA G. ADAMS AND GEORGE I. MATSUMOTO
}

\section{PURPOSE}

The primary objective of this activity is to predict how coastal processes, such as tides, affect salinity, temperature, and nitrate levels in a type of estuary, called a slough. Real-time data from the Elkhorn Slough National Estuarine Research Reserve in Monterey, California, will be used to test predictions. In addition to collecting, graphing, and interpreting real-time data, students will learn how nitrates enter the estuary, and they will gain a better understanding of the interconnectedness of all bodies of water, especially estuaries.

\section{AUDIENCE}

This activity is designed for undergraduate marine biology, oceanography, ecology, and environmental science classes, or advanced high school science classes in these subjects. A version of this lab was piloted in a lower-division ecology laboratory course at Georgia Institute of Technology.

\section{BACKGROUND}

Estuaries are incredibly important wetlands that are influenced by rivers and the ocean; therefore, they vary in their salinity, water depth, and temperature (Kennish, 2002). Estuaries are very productive habitats that serve as nurseries to many aquatic organisms and are home to many coastal bird species (Emmett et al., 2000). Coastal wetlands also buffer storm events and naturally filter out sediments, nutrients, and even some pollutants. Levels of nutrients, such as nitrogen, affect the overall health of

LISA G. ADAMS (ladams@kennesaw.edu) is Assistant Professor, Department of Biology and Physics, Kennesaw State University, Kennesaw, GA, USA. GEORGE I. MATSUMOTO is Senior Education and Research Specialist, Monterey Bay Aquarium Research Institute, Moss Landing, CA, USA. an aquatic ecosystem and can have both positive and negative effects, depending on their concentrations (Caffrey et al., 2003). Nitrogen is often considered a limiting factor for estuarine phytoplankton (Pinckney et al., 2001). Studies show that nutrient loading in estuaries over time can lead to eutrophic plankton growth, oxygen depletion, and changes in species composition (Lotze et al. 2006).

We will see in our investigation that nitrate levels found in estuaries have both natural and anthropogenic origins. Nitrates found in leaf litter, organic debris, and nutrient-rich soil naturally enter our riverine systems from runoff during rain events. Some nutrients enter the estuary from the ocean; however, their total contribution is much less than that of the fresh water (see the General Comments section for further discussion on this topic). Humans contribute to the nitrogen load in aquatic systems in many ways, including agricultural practices, sewage, wastewater, industrial wastes, and stormwater drains. McClelland and Valiela (1998) found a relationship between nitrogen levels in groundwater and estuarine producers. Their findings suggest a link between the levels of nitrogen originating from land-derived activities (wastewater) and primary production in estuaries.

This lab focuses on agricultural sources of nitrates. Areas that are farmed generally contain greater nitrogen levels in their surface water and groundwater due to the application of fertilizers, and therefore, the bodies of water located in these watersheds exhibit greater nitrogen loads. Even individuals living hundreds of miles inland from the nearest ocean can affect our coastal ecosystems through daily landscaping practices that include the application of fertilizers. Due to the interconnectedness of all bodies of water, eventually these backyard tributaries empty into our coastal waters and affect the nutrient balance of our estuaries. 
Figure 1. Location of the Land/Ocean Biogeochemi-

cal Observatory (LOBO) moorings within the

Elkhorn Slough National

Estuarine Research Reserve

in California. The smaller

inset figure is from the

Elkhorn Slough Web site

(http://www.elkhornslough.

org/map.htm), and the

mooring location figure is

taken from the LOBO Web

site (http://www.mbari.org/

staff/coletti/lobogps.html),

where more precise GPS

coordinates can be found.

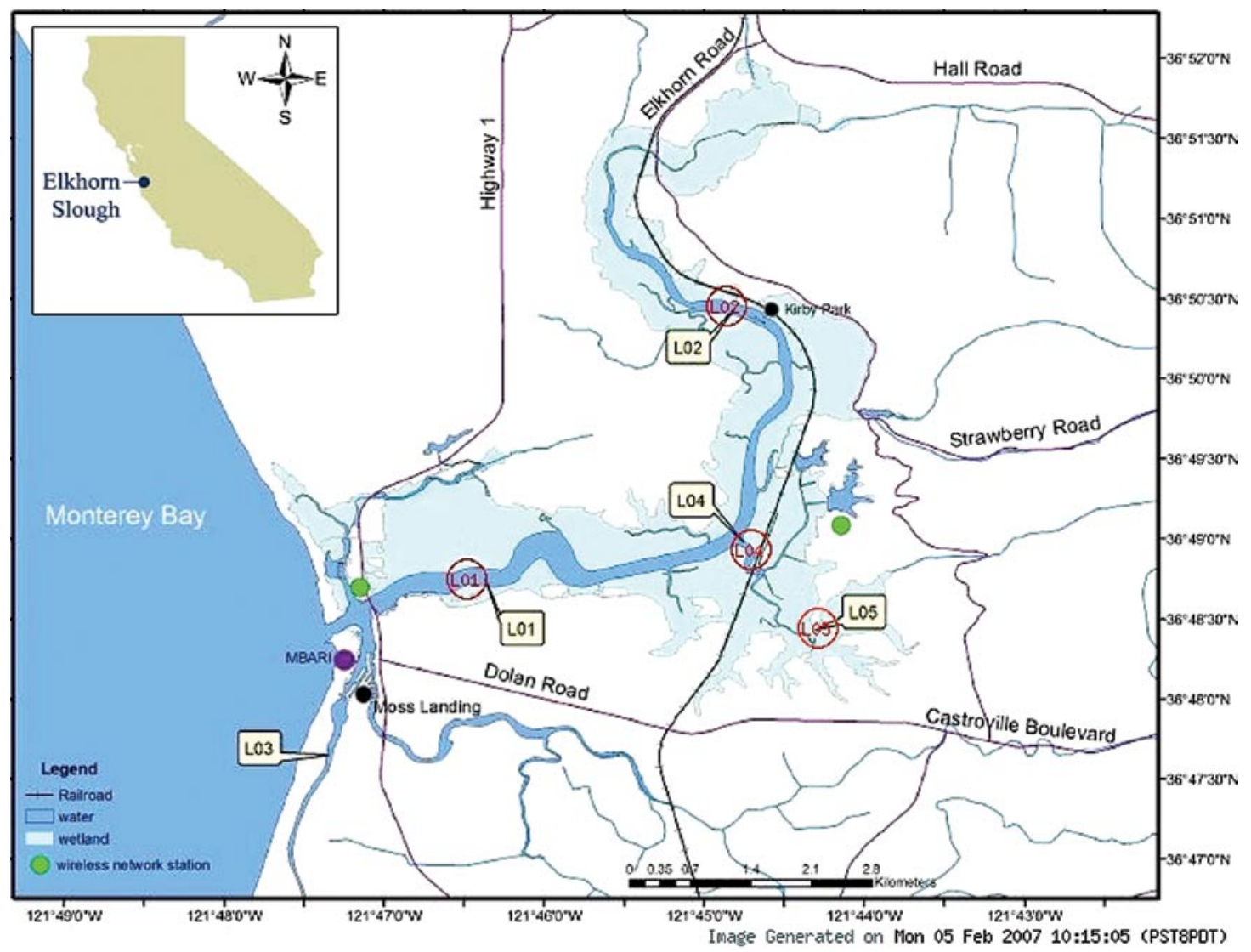

To better understand the relationships among tides, salinity levels, temperatures, and nitrate levels in an estuary, students will collect real-time data from observatories set up on buoys in the Elkhorn Slough, the Salinas River, and Moss Landing Harbor. The watershed in this geographic area (Figure 1) is heavily farmed and is located in Monterey County, California. These observatory buoys are strategically placed in the estuary and equipped with various sensors that continually monitor physical, chemical, and biological parameters (Figure 2). The sensors detect changes in nitrogen levels, allowing us to monitor how events such as seasonal precipitation patterns, simple rain events, and even tidal changes affect salinity levels, temperatures, and nitrate levels in the estuary. These real-time data are available not only to scientists but also to students, environmental agencies, and the general public (http://www.mbari.org/lobo). The

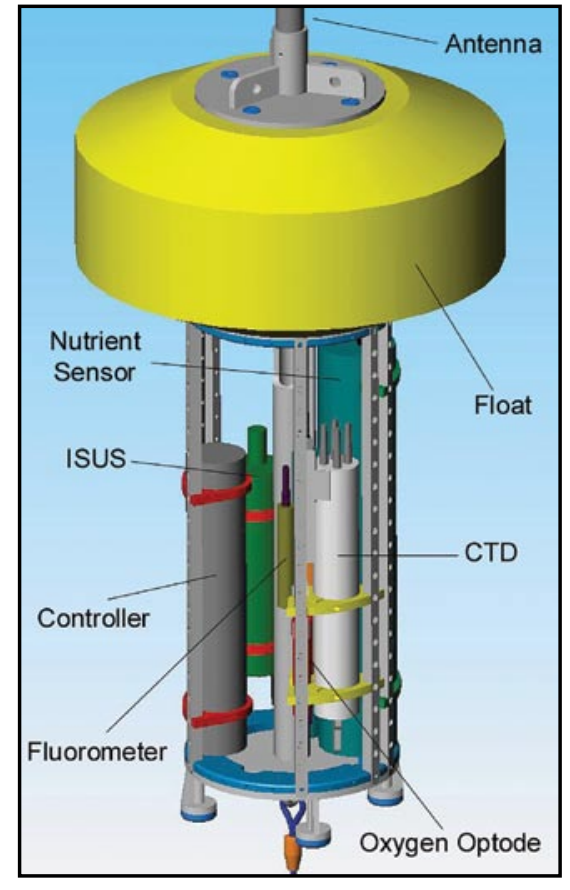

Figure 2. The instrumentation integrated into the LOBO moorings is a combination of commercially available (YSI 9600 nitrate monitor, Aanderaa oxygen optode, Sea Bird conductivity-temperature-depth sensor [CTD], fluorometer and turbidity sensors, RD Instruments acoustic Doppler current profiler) and "in house" (in situ ultraviolet spectrophotometer [ISUS]) technology. Combined with a mooring system that allows for long-term deployment and rapid data transmission through a wireless local area network, the sensors can return near-real-time information for extended deployment periods. For more detailed information on the mooring instrumentation, go to http://www.mbari.org/lobo/ instruments.htm. 
observatories were developed and deployed and are monitored by the Monterey Bay Aquarium Research Institute (MBARI) for the Land/Ocean Biogeochemical Observatory (LOBO) project, funded by MBARI and a National Science Foundation BioComplexity Grant (ECS-0308070). Besides promoting an understanding of basic tidal processes, the nitrogen data collected from the LOBO project provide valuable information that may help protect critical estuarine habitats from further eutrophication.

\section{RESEARCH QUESTIONS}

How do coastal processes affect salinity, temperature, and nitrate levels in a slough? How do nitrates enter the estuary, and how do coastal processes, like tides, affect nitrate levels? How do salinity, temperature, and nitrate levels fluctuate during tidal cycles?

\section{MATERIALS}

Colored Pencils

Computers

Internet connections

Printers

\section{ACTIVITY}

1. Find a partner to work with and go to the following Web site: http://www.mbari.org/earth/Coastal/Elkhorn_case/ elkhorn.htm. Read the introductory paragraph for the Elkhorn Slough Nitrogen Case Study.

2. Click on the LOBO link to access the Web site for the LOBO project (www.mbari.org/lobo). Read the introductory paragraph, which briefly outlines this project.

3. Click on the link below to open a news article that was published in the Salinas Californian. Read the article that discusses the LOBO project and the Elkhorn Slough. (http:// www.mbari.org/staff/coletti/docs/Californian_Article.pdf)

4. Referring to the map of the Elkhorn Slough area (Figure 1), locate the buoys. Please note that two of the buoys are technically not in the Elkhorn Slough: Buoy LO3 is located in Old Salinas River and buoy LML is in Moss Landing Harbor. The Old Salinas River drains a watershed that is heavily farmed. Buoys 1, 2, 4, and 5 are also in areas that are heavily farmed, but are located in the National Estuarine Research Reserve System, which is more tightly regulated.
5. On the map (Figure 1), predict the origin and pathway that the nitrates follow as they move through the Elkhorn Slough. Using two different colored pencils, indicate which color represents the natural source and which represents the anthropogenic source of nitrates.

6. After thinking about tides and nitrate levels, formulate a prediction about how tidal cycles affect each of the variables listed below. Provide a rationale for each prediction. We will be collecting data from buoy LO1 in the Elkhorn Slough to test your predictions.

Prediction A: Tidal cycles and salinity levels in the slough

Prediction B: Tidal cycles and temperature in the slough

Prediction C: Tidal cycles and nitrate levels in the slough

7. The following link will bring you to the LOBOVIZ Web site: http://www.mbari.org/lobo/loboviz.htm. LOBOVIZ is a network data visualization program. This page provides instructions on how to collect real-time data from the buoys. Follow the directions below when selecting the data for your graph. When prompted, choose the following options.

\section{How many graphs? Choose One}

Select Location(s): LO1 Surf recommended (Lobo

Buoy \#1, surface measurements)

\section{Select One X variable: Choose DATE}

Select Y variable(s): Select Nitrate, Water Depth, Salinity, and Temperature (this can be done by holding down the control or shift button on the computer keypad). What Dates? Specify Start/End Date. When prompted for the dates, first start with June 4, 2004, to June 8, 2004. This data set provides daily and repeatable patterns for each of the variables being graphed.

\section{All other options are on a default setting and do not} need to be changed.

PRESS SEND (lower right) and print your graph.

8. As a class effort, organize yourselves so that each group selects a different month. List the month that your group will investigate.

9. Now, try your own four consecutive dates from the month that your group selected by following the directions listed above. Please be aware that the dates selected could include a rain event or other factors that may have influenced the data. Look to see if you have a rhythmic and consistent pattern in your graphs, like that for the June 4, 2004, to June 8, 2004 data set. This observation will allow you to make some generalizations about your variables. If your 
data set includes any unpredictable peak or valley, you may want to select different dates. If necessary, continue your search for a data set that is based upon four consecutive dates, where the curves for each graph seem to repeat themselves on a daily cycle. Print your graph and label the low and high tides.

10. To test your predictions about salinity, temperature, nitrate levels, and tidal cycles, compare your data with your original predictions. Did your data set support your predictions? If not, explain how they differed.

Prediction A: Tidal cycles and salinity levels in the slough

Prediction B: Tidal cycles and temperature in the slough

Prediction C: Tidal cycles and nitrate levels in the slough

11. Circulate around the room and compare your graph with the graphs of other groups that differ by dates or seasons. Are there differences in the trends observed in these graphs? If so, which month varied most from your data set?

12. Collaborate with other groups and explain any observed monthly differences between your graphs.

13. Now, based on your findings, redraw your map (Figure 1) representing how nitrates enter and move through the slough. Use different colored pencils this time so that you can compare your predicted pathways with your findings. Explain any differences that you observe.

14. Thinking in terms of Monterey's climate, what factor may have influenced these monthly/seasonal differences? After reviewing your data, you may see two peaks of nitrates per day. There are actually two sources for these increases, one natural and one anthropogenic. The anthropogenic effect is discussed above. The LOBO Web site (http://www. mbari.org/lobo/casestudy1.htm) explains how these relationships can be interpreted. There will be a graph that summarizes the data for one of the observatories, buoy LO1.

15. List one way that humans have affected the nitrate levels in the Elkhorn Slough and the Old Salinas River.

16. List at least one natural source of nitrates that may have contributed to the daily fluctuations of nitrates in the slough. When thinking about a possible natural source of nitrates, consider the bathymetry of Monterey Canyon, which is very deep. During high tide in Monterey, deep water is carried by internal waves to the surface and inshore.

17. The members of each group should present their graph to the class and explain the relationships among tidal cycles, salinity, temperature, and nitrate levels and note any seasonal effects that were observed.
18. The consequence of high nitrate levels was briefly discussed in the article in the Salinas Californian. Briefly describe how high nitrate levels can have both positive and negative effects in an aquatic ecosystem.

19. Support the statement that estuaries are interconnected with both the ocean and fresh water and that they serve important roles in other ecosystems.

20. Extra credit: select a different buoy and/or a different measurement depth and run the exercise again.

\section{GENERAL COMMENTS}

- The estimated time to complete this activity is one lab period (2-3 hours, depending upon the student).

- Education And Research: Testing Hypotheses (EARTH) (http://www.mbari.org/EARTH): EARTH is an internally funded (supported by the Monterey Bay Aquarium Research Institute [http://www.mbari.org]) Web site and teacher workshop series that focuses on data distribution (near-real-time and archived) with supporting lesson plans and activities. For the past four years, EARTH has engaged a number of educators and has been presented at National Marine Educators Association (NMEA), American Geophysical Union (AGU), and American Society of Limnology and Oceanography (ASLO) meetings. As the Ocean Observatory Initiative (OOI) ramps up, EARTH is poised to provide educators with access to observatory data.

- Nitrate Sources in the Elkhorn Slough: There are two potential sources for nitrate input into the slough waters. The obvious source is from land via the Old Salinas River that enters at the south end of Moss Landing Harbor. This terrestrial, anthropogenic source results in high-nitrate/lowsalinity waters that travel downriver on the ebb tide, mix a little in the coastal zone, and then re-enter Elkhorn Slough on the flood tide. The natural oceanic input of nitrates is far less than the terrestrial source and is a bit more complex. The Monterey Submarine Canyon generates large internal tides that propagate like tidal bores up the canyon. These internal waves carry cold, oxygen-depleted, high-nitrate water from $\sim 100 \mathrm{~m}$ depth up the Monterey Submarine Canyon to the canyon head, which is also the harbor entrance. The rising tide can then carry that water into the slough. This is an unusual circumstance, and it is uncommon to have internal oceanic waves influencing nitrate levels in estuaries. To further complicate the issue, this connection between the in- 
ternal waves and the estuary are strongest during upwelling events (Chapin et al. 2004).

- More information about aquatic biochemistry can be found at the LOBO site in the Additional Online Resources section.

- Students should consider seasonal variations, especially precipitation patterns, in the Monterey area when interpreting their graphs. For more information on the climate in this area, please refer to the Additional Online Resources section below.

\section{POSSIBLE MODIFICATIONS}

The National Estuarine Research Reserve System (http://nerrs. noaa.gov/) provides links to near-real-time data from individual reserve sites on its centralized data management office Web site (http://cdmo.baruch.sc.edu/). Use the pull-down menu on the left side (About Data, Get Data, and Available Data) to generate a list of available data at each reserve in the United States. There is also a link to real-time data from a data distribution system operated by the National Weather Service (http://nerrs. noaa.gov/ioos/realtime_map.html). These resources will enable you to integrate data from your region into the activity. ⿷匚

\section{REFERENCES}

Caffrey, J.M., N.E. Harrington, I.P. Solem, and B.B. Ward. 2003. Biogeochemical processes in a small California estuary. 2. Nitrification activity, community structure and role in nitrogen budgets. Marine Ecology Progress Series 248:27-40.

Chapin, T.P., J.M. Caffrey, H.W. Jannasch, L.J. Coletti, J.C. Haskins, and K.S. Johnson. 2004. Nitrate sources and sinks in Elkhorn Slough, California: Results from long-term continuous in situ nitrate analyzers. Estuaries 27(5):882-894.
Emmett, R., R. Llanso, J. Newton, R. Thom, M. Hornberger, C. Morgan, C. Levings, A. Copping, and P. Fishman. 2000. Geographic signatures of North American West Coast estuaries. Estuaries 23(6):765-792.

Kennish, M.J. 2002. Environmental threats and environmental future of estuaries. Environmental Conservation 29(1):78-107.

Lotze, H.K., H.S. Lenihan, B.J. Bourque, R.H. Bradbury, R.G. Cooke, M.C. Kay, S.M. Kidwell, M.X. Kirby, C.H. Peterson, and J.B.C. Jackson. 2006. Depletion, degradation, and recovery potential of estuaries and coastal seas. Science 312:1,806-1,809.

McClelland, J.W., and I.Valiela. 1998. Linking nitrogen in estuarine producers to land-derived sources. Limnology and Oceanography 43(4):577-585.

Pinckney, J.L., H.W. Paerl, P. Tester, and T.L. Richardson. 2001. The role of nutrient loading and eutrophication in estuarine ecology. Environmental Health Perspectives Supplements 109(suppl 5):699-706.

\section{ADDITIONAL ONLINE RESOURCES}

Elkhorn Slough Foundation http://www.elkhornslough.org/index.html

General Background on Tides http://www.oceanservice.noaa.gov/education/kits/tides/

Tide Processor and Display for Elkhorn Slough and Moss Landing, CA http://www2.mbari.org/coletti/pagetide.cgi

National Estuarine Research Reserve System http://nerrs.noaa.gov/

LOBO Project Background (includes a link for photographs of the slough) http://www.mbari.org/lobo/\#Introduction

Aquatic Biochemistry, LOBO http://www.mbari.org/lobo/biogeochem.html

Buoy locations for LOBO http://www.mbari.org/lobo/network.htm

Webcam image for Elkhorn Slough, LOBO http://www.mbari.org/staff/coletti/lobocam.html

Monterey County Weather http://montereyinfo.org/?p=monterey_weather http://www.weather.nps.navy.mil/wx/current/mry_fcst.html

\section{HANDS-ON OCEANOGRAPHY}

Visit www.tos.org/hands-on to download activities or for more

information on submitting an activity of your own for consideration.
Hands-On Oceanography provides an opportunity for you to publish teaching materials developed for undergraduate and/or graduate classes in oceanography. Activities, include, but are not limited to, computer-based models and laboratory demonstrations that actively engage students (i.e., activities where students have to make decisions, record results, and interpret results). All submissions are peer-reviewed. Publication of teaching materials may contribute to the broader impact of NSF-funded research.

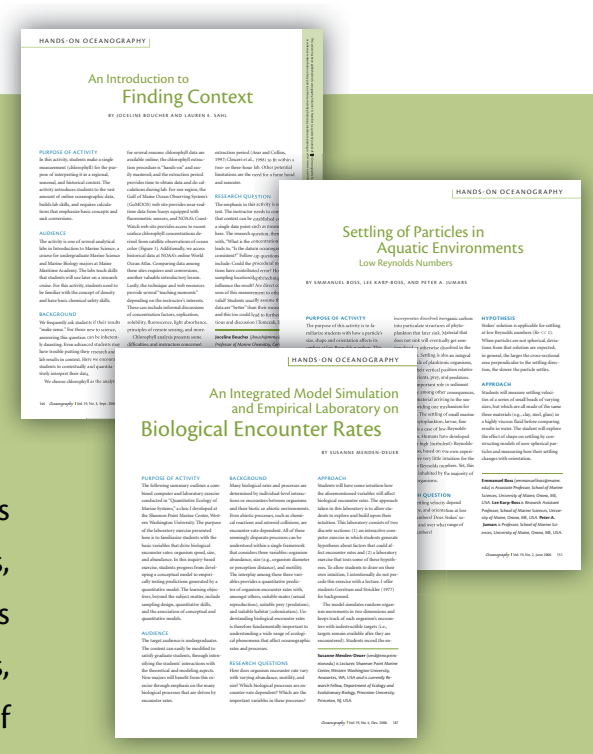

